\title{
Impact of micro- and nanograzers on phytoplankton assessed by standard and size-fractionated dilution grazing experiments
}

\author{
Albert Calbet* ${ }^{*}$ Isabel Trepat, Rodrigo Almeda, Violeta Saló, Enric Saiz, \\ Juan Ignacio Movilla, Miquel Alcaraz, Lidia Yebra, Rafel Simó
}

Marine Zooplankton Ecology Group, Institut de Ciències del Mar (CSIC), P. Marítim de la Barceloneta 37-49, 08003 Barcelona, Spain

\begin{abstract}
Grazing by microzooplankton is typically assessed by dilution experiments of the whole natural community. However, in many ecosystems these experiments actually include not only micrograzers but also nanograzers. We discerned the relevance of micro- and nanograzers under contrasting trophic situations in the coastal NW Mediterranean throughout a seasonal cycle. We measured the grazing upon total, $<10 \mu \mathrm{m}$, and $>10 \mu \mathrm{m}$ chlorophyll $a$ in 11 standard dilution experiments. We also conducted simultaneous dilution experiments with the $<10 \mu \mathrm{m}$ planktonic community, to assess the potential impact of $<10 \mu \mathrm{m}$ grazers when released of predatory pressure by larger consumers. From September 2005 to May 2006 the microbial grazers consumed less than half of the total phytoplankton production. From June 2006 and for the whole summer period, the grazing on total phytoplankton increased, ranging from 76 to $104 \%$ of the primary production consumed per day. On annual average, microbial grazers consumed $56 \%$ of the total primary production. Grazing on $<10 \mu \mathrm{m}$ phytoplankton was very variable, from not significant (January and March) to $>100 \%$ of the primary production consumed daily in July and August (the average impact for the whole study period was $58 \%$ ). Grazing impact on $>10 \mu \mathrm{m}$ cells was very low, only significant in 5 out of 11 experiments (average impact of $23 \%$ of the $>10 \mu \mathrm{m}$ primary production consumed daily, range 23 to $71 \%$ ). When the entire microbial community was size-fractioned by $10 \mu \mathrm{m}$, the potential impact of $<10 \mu \mathrm{m}$ nanograzers was evident for most of the year, although during the spring the differences between the impact on phytoplankton $<10 \mu \mathrm{m}$ measured in these experiments and in standard (unfiltered) dilutions were higher. During the warmer months (July and August) the size distribution of the grazers' community slightly shifted towards $<10 \mu \mathrm{m}$ organisms $(72$ to $88 \%$ of the biomass of grazers were $<10 \mu \mathrm{m}$ cells). Heterotrophic flagellates stood out as very relevant grazers in this system. In summary, the data suggest that the coastal NW Mediterranean is a system in which microzooplankton $(>10 \mu \mathrm{m}$ organisms) weakly control the primary producers during the cold season (winter and most of the autumn), switch to nano-sized heterotrophic prey during spring, partially suppressing the impact of this group on phytoplankton, and finally are replaced by nanograzers during the warmer months (end of the summer period), heavily impacting the dominant small primary producers.
\end{abstract}

KEY WORDS: Size-fractionated dilutions - Microzooplankton - Nanograzers · Microbial grazers · Phytoplankton $\cdot$ NW Mediterranean

\section{INTRODUCTION}

Microzooplankton stand out as the main grazers in most marine ecosystems, from ultra-oligotrophic to upwelling regions (Calbet 2001, Calbet \& Landry 2004). It is estimated that, on average, $2 / 3$ of the primary produc- tion (PP) circulates through this group (Calbet \& Landry 2004), the remaining $1 / 3$ being susceptible to larger grazers, viral attacks, cellular death, sedimentation, and advection losses. Most of this information has been obtained through experimentation using the dilution technique (Landry \& Hassett 1982). The technique, 
based on sequential dilutions of natural communities, is not free of artifacts (e.g. Gallegos 1989, Dolan et al. 2000, Dolan \& McKeon 2005, Agis et al. 2007). In general, these artifacts can be overcome by precise execution of the method, and in certain situations by the use of alternative equations in data analyses (Gallegos 1989). One of the main advantages of the technique is that it provides an estimate of the whole microzooplankton community's (sensu lato) grazing impact on PP with relatively little manipulation. This can also be seen as a limitation, because it confines microzooplankton into a black box in which the relevance of their distinct components (e.g. nanoflagellates, ciliates, dinoflagellates, small metazoans, etc.) is pooled together. Traditionally, ciliates have been chosen as archetypes of microzooplankton, and their abundance and grazing activity have been usually used to approximate the impacts of microzooplankton (e.g. Dolan \& McKeon 2005). However, flagellates may represent a sizable loss factor for the phytoplankton of unproductive systems (Sherr \& Sherr 1988, Wikner \& Hagström 1988, Calbet \& Landry 1999), and heterotrophic dinoflagellates can be major grazers of diatom blooms (Sherr \& Sherr 1992, Strom \& Strom 1996, Stelfox-Widdicombe et al. 2004, Leising et al. 2005). Metazoan microzooplankton (e.g. marine rotifera, nauplii, and meroplanktonic larvae) have also been identified as large contributors to microzooplankton grazing on certain occasions (Calbet et al. 2003, Turner 2004). We feel, therefore, that for a better comprehension of marine food webs, it is time to open the microzooplankton black box and have a closer look at the main grazers in aquatic ecosystems. A first approach to accomplish such a task could be size fractionation of natural planktonic communities, with the aim at isolating the main grazers of each size fraction (Wikner \& Hagström 1988, Calbet et al. 2001). Previous attempts comparing the growth of prey in unfiltered and prescreened water, besides presenting multiple artifacts (e.g. differential release of nutrients and organic matter result of the filtration process), showed the difficulty of providing a clear estimate of the grazing activity in each size fraction because no controls without grazers were possible. However, by conducting dilution experiments with previously size-fractionated natural water we can estimate the potential grazing activity of each size fraction (Reckermann \& Veldhuis 1997). Thus, we can better identify the most relevant fraction of grazers in the community. In an idealized, oversimplified food web in which second-order consumers prey upon firstorder consumers and phytoplankton (Fig. 1), the truncation of the food web by size fractionation may produce severe modifications in the transfer of matter and energy and, globally, in the efficiency of the systems. These changes would be apparent in dilution experiments. The possibilities are infinite, depending on the

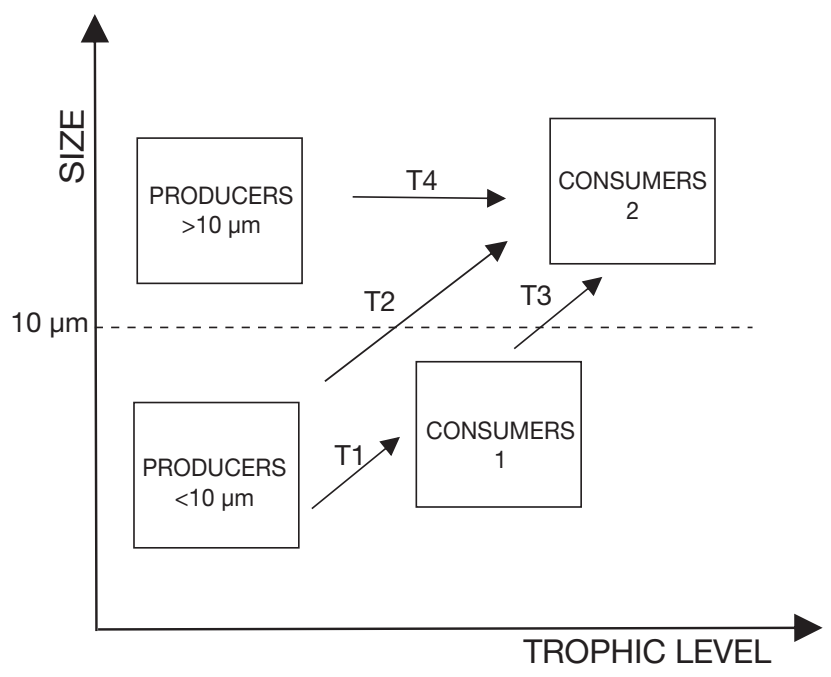

Fig. 1. A simple food-web scenario with 2 groups of consumers (Consumers 1 and 2) and 2 groups of prey (Producers $>10$ and $<10 \mu \mathrm{m})$. $\mathrm{T}=$ transfer of matter between compartments

relative biomass of the different trophic compartments, their potential growth rates, and the efficiency of transfer of matter through them. We can outline 2 extreme situations. In Fig. 1 the absolute transfer from the different compartments is expressed as T1, T2, T3 and T4. If T2 is much higher than T1 (most grazing a result of $>10 \mu \mathrm{m}$ consumers), the truncation of the food web in a $10 \mu \mathrm{m}$ size-fractionated experiment would render lower grazing rates on $<10 \mu \mathrm{m}$ phytoplankton than those from unfiltered experiments. The release of pressure on Consumers 1 would likely cause an increase in their populations; however, it is unlikely in the short duration of a dilution experiment ( $24 \mathrm{~h}$ ) that these consumers can take over and greatly impact the populations of producers unless they were in turn heavily controlled by Consumers 2. In the opposite situation in which a flourishing population of small consumers are the major grazers of PP, Consumers 2 may or may not be controlling the abundances of these small grazers (Consumers 1). If there is a strong coupling between grazers, the removal of Consumers 2 in the size-fractionated experiments would be sequentially transferred down to the food web, mediated by trophic cascade interactions, resulting in an enhanced grazing pressure on primary producers.

It is important to identify these unbalanced food-web scenarios when conducting dilution experiments because they can result in unrealistically lower phytoplankton grazing mortalities, and even reverse dilution regression slopes, due to differential effects of dilutions on the distinct grazers during the incubations (Gallegos 1989, Agis et al. 2007). The dilution of natural communities with filtered seawater may release 
Consumers 1 from grazing pressure in the most diluted treatments, leading to an exaggerated growth of these grazers, and a lower than expected net growth rate of phytoplankton (lowering the overall slope of the dilution regression line).

Previous assays using $20 \mu \mathrm{m}$ size-fractionated dilution experiments (Reckermann \& Veldhuis 1997, Lessard \& Murrell 1998, authors' unpubl. data) did not result in important different grazing impacts upon primary producers compared with standard dilutions (filtered through $200 \mu \mathrm{m})$; this was probably because most microzooplanktonic grazers passed through the $20 \mu \mathrm{m}$ mesh. It is expected, however, that smaller size fractions should render a different result (Reckermann \& Veldhuis 1997). In the present study, we present data from a series of experiments where the results of standard dilutions with unfiltered water are compared with those obtained with $10 \mu \mathrm{m}$ reverse-filtered natural water. We chose $10 \mu \mathrm{m}$ because this size fraction represents a closer approximation to what is commonly accepted as nanoplankton (flagellates and small dinoflagellates), not including most of the 'typical' microzooplanktonic grazers (i.e. ciliates and large dinoflagellates). Our test area was the coastal NW Mediterranean, which was sampled monthly over an annual cycle. The aims of the study were to describe the contribution of different size fractions of grazers to total community impacts in very contrasted trophic situations throughout a seasonal cycle, and to discern the importance of the nano-sized fraction. In addition, these experiments provide unique and valuable data on the microbial grazing activity in Mediterranean coastal waters.

\section{MATERIALS AND METHODS}

Experimental setup. From September 2005 to September 2006 we conducted 11 series of dilution experiments (see Table 1) to assess the grazing of the entire microbial community (standard dilution experiments with unfiltered water; Landry \& Hassett 1982) and of nanozooplankton (here understood as the heterotrophs that pass through a $10 \mu \mathrm{m}$ mesh nylon netting in sizefractionated dilution experiments) on the primary producers of the coastal NW Mediterranean $(1.5 \mathrm{~km}$ off Barcelona, $40 \mathrm{~m}$ water-column depth). The water for the experiments was collected at $5 \mathrm{~m}$ depth around 11:00 h local time with a $15 \mathrm{l}$ transparent hydrographic bottle, gently transferred to carboys, and transported to the laboratory. We measured the light intensity and temperature at the depth of water collection with a LICOR LI-1400 data logger (LI-193SA spherical quantum sensor) and a YSI 30 portable temperature meter, respectively. Once in the laboratory we gently siphoned the water into a 501 bucket and mixed it with care to avoid generating bubbles that could damage delicate ciliates (Broglio et al. 2004). We used part of this water to prepare the standard dilution series (with unfiltered natural water), and the remaining water was reverseflow filtered by submerging a $30 \mathrm{~cm}$ diameter PVC cylinder with a bottom screen of $10 \mu \mathrm{m}$ mesh for the $<10 \mu \mathrm{m}$ size-fractionated dilution series. We are aware this procedure may damage some ciliates (Gifford 1985); however, our goal was to obtain mostly flagellated protozoans as main grazers in these experiments. The experimental water was diluted with $0.2 \mu \mathrm{m}$ filtered seawater (gravity filtration through a Pall Acropak 0.8/0.2 500 capsule previously flushed with diluted $\mathrm{HCl}$ and thoroughly rinsed with deionized water) to obtain 2 replicate bottles (2.3 1 polycarbonate) with the proportions $25,50,75$, and $100 \%$ of the experimental water. The dilution bottles were amended with a nutrient mixture $\left(15 \mu \mathrm{M} \mathrm{NH} \mathrm{NH}_{4} \mathrm{Cl}\right.$ and $\left.1 \mu \mathrm{M} \mathrm{Na} \mathrm{NPO}_{4}\right)$ to guarantee that nutrients did not become limiting in any treatment; 2 additional $100 \%$ experimental water (i.e. not diluted) bottles were prepared without nutrients to assess the natural growth of algae. The nutrient concentration in the water at the time of the experiments (see Table 1) was always lower than the concentration in the amended bottles. All bottles were incubated at in situ temperature in a large (600 l) outdoor incubator with open-circuit water running from the coastal seawater intake at the Institut de Ciències del Mar, Barcelona, Spain. Natural sunlight was dimmed with appropriate neutral plastic mesh to mimic the light intensity at $5 \mathrm{~m}$ depth, usually between 33 and $50 \%$ of the irradiance at the surface. To minimize the settling of algae, and to ensure the homogeneity of the light conditions, we gently mixed the bottles by repeatedly turning them upside down and moving them around the incubator $\geq 3$ times $\mathrm{d}^{-1}$. The incubations lasted for ca. $24 \mathrm{~h}$.

Because we did not screen the standard (unfiltered) dilution series, the experimental suspension might have contained some mesozooplankton. Visual examination of the bottles did not reveal the presence of large organisms. In addition, the expected mesozooplankton grazing impact on the microbial community of these waters is seldom significant (Broglio et al. 2004).

Sample collection and analyses. Initial and final concentrations of total and $>10 \mu \mathrm{m}$ chlorophyll a (chl a) were determined by filtering 75 to 300 and 100 to $500 \mathrm{ml}$ of water through GF/F Whatman and $10 \mu \mathrm{m}$ pore-size polycarbonate Nuclepore filters, respectively. The $<10 \mu \mathrm{m}$ chl a was obtained by the difference between total and $>10 \mu \mathrm{m} \mathrm{chl}$ a. For the size-fractionated dilution experiments we used only GF/F filters. It should be noted that the concentrations of chl a obtained by prescreening through a $10 \mu \mathrm{m}$ nylon mesh and later filtering through GF/F, and the ones resulting from the difference between GF/F (total) and 
polycarbonate $>10 \mu \mathrm{m}$ membrane filters were not significantly different (paired $t$-test, $\mathrm{p}=0.05$ ). This indicates that both procedures had similar retention spectra. The filters were frozen at $-80^{\circ} \mathrm{C}$ and later analyzed fluorometrically after acetone extraction according to Parsons et al. (1984). The composition of the initial microbial community of both standard (unfiltered) and $<10 \mu \mathrm{m}$ treatments was also assessed. For nanoflagellates, 40 to $100 \mathrm{ml}$ samples were preserved in glutaraldehyde (1\% final concentration), filtered onto $2 \mu \mathrm{m}$ pore-size black polycarbonate membrane filters and stained with DAPI ( $5 \mathrm{\mu g} \mathrm{ml}^{-1}$ final concentration) for $5 \mathrm{~min}$. At least 200 cells were counted and classified as auto- or heterotrophic according their fluorescence for chlorophyll. Fifty cells were sized and converted into carbon using a conversion factor of $0.22 \mathrm{pgC} \mathrm{m}^{-3}$ (Børsheim \& Bratbak 1987). To determine the concentration of dinoflagellates and ciliates, $100 \mathrm{ml}$ samples were fixed with $1 \%$ acidic Lugol's solution, and allowed to settle for $48 \mathrm{~h}$ in $100 \mathrm{ml}$ Utermöhl chambers. The whole chamber was counted under an inverted microscope (Nikon DIAPHOT 200) at 200× magnification. Fifty cells were sized and converted into carbon

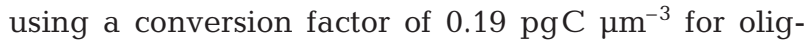

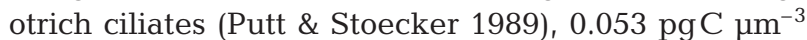
for tintinnids (Verity \& Langdon 1984), and the equation $\mathrm{pgC}=0.760 \times$ volume $^{0.819}$ (Menden-Deuer \& Lessard 2000) for dinoflagellates. Because microplankton were preserved with acidic Lugol's solution, no distinction between strict heterotrophs and auto/mixotrophs was made for ciliates and dinoflagellates. Samples $(2 \mathrm{ml})$ for Prochlorococcus sp. and Synechococcus sp. were preserved in paraformaldehyde + glutaraldehyde $(1 \%+0.05 \%$ final concentration, respectively) and stored at $-80^{\circ} \mathrm{C}$ for flow cytometry analysis with a FACSCalibur (Becton \& Dickinson) flow cytometer with a laser emitting at $488 \mathrm{~nm}$. The in situ concentrations of ammonium and phosphate were determined with an Alliance Evolution II autoanalyzer, following a modification of the methods in Grasshoff et al. (1999).

For all experiments, Model I linear regressions were used to obtain the slope (grazing mortality rate, $\mathrm{d}^{-1}$ ) of the equation relating the fraction of undiluted water $(x)$ and the net phytoplankton growth rates $(y)$ estimated from changes in chl a concentration during incubation. Because the intercept of the equation would provide an overestimation of phytoplankton instantaneous growth rates (nutrients were added to these bottles), these rates $\left(\mu, d^{-1}\right)$ were obtained from net growth in unamended bottles plus mortality rate $(m$, $\mathrm{d}^{-1}$; Landry \& Hassett 1982). PP was calculated according to the formulae of Landry et al. (2000):

$$
\begin{gathered}
\mathrm{PP}=\mu \times C_{\mathrm{m}} \\
C_{\mathrm{m}}=C_{0}\left(\mathrm{e}^{(\mu-m) t}-1\right) /(\mu-m) t
\end{gathered}
$$

where $C_{\mathrm{m}}$ is the mean phytoplankton concentration during the incubations, $t$ is the incubation time (d), and $C_{0}$ is the initial phytoplankton concentration (in chl a). The percentage of the phytoplankton standing stock removed daily by grazers was calculated as $G \times$ $100 /$ chl a initial, where $G$ was obtained by multiplying the phytoplankton grazing mortality rate $(m)$ by $C_{\mathrm{m}}$ (Landry et al. 2000, Calbet \& Landry 2004).

\section{RESULTS}

\section{Microbial community}

Although the data are insufficient for defining in detail the seasonal cycle in the area, we observed highly contrasted situations during the study. Two modest peaks of total chl a $\left(<1.7 \mu \mathrm{g} \mathrm{chl} \mathrm{a}{ }^{-1}\right)$ occurred in October 2005 and March 2006, followed by a slow decline over the subsequent samplings (Table 1). During those periods in which total chl a concentration was $>0.5 \mu \mathrm{g} \mathrm{l}^{-1},>40 \%$ of phytoplankton biomass occurred in the larger fraction $(>10 \mu \mathrm{m})$. For the rest of the year (mostly during summer), phytoplankton $<10 \mu \mathrm{m}$ largely dominated the community (Table 1). This was not only evident in the chl $a$, but also in a shift towards smaller species in the diatom community (Table 2). The retention efficiency on diatoms by the $<10 \mu \mathrm{m}$ nylon filter varied from $33 \%$ (range 12 to $44 \%$ ) when the community was dominated by Nitzschia and Pseudo-nitzschia genera (warm months) to $86 \%$ (range 74 to $96 \%$ ) for the rest of the year. Remarkable features

\begin{tabular}{|c|c|c|c|c|c|c|c|}
\hline Expt & Date & $\begin{array}{l}\text { Temp. } \\
\left({ }^{\circ} \mathrm{C}\right)\end{array}$ & $\begin{array}{c}\mathrm{PO}_{4} \\
\left(\mu \mathrm{mol} \mathrm{l}{ }^{-1}\right)\end{array}$ & $\begin{array}{c}\mathrm{NH}_{4} \\
\left(\mu \mathrm{mol} \mathrm{l} l^{-1}\right)\end{array}$ & $\begin{array}{c}\text { Total } \\
\text { chl a } \\
\left(\mu g 1^{-1}\right)\end{array}$ & $\begin{array}{c}>10 \mu \mathrm{m} \\
\operatorname{chl} a \\
\left(\mu \mathrm{g} \mathrm{l}^{-1}\right)\end{array}$ & $\begin{array}{c}\% \\
\text { chl a } \\
>10 \mu \mathrm{m}\end{array}$ \\
\hline Sep-05 & $14 \mathrm{Sep} 05$ & 23.50 & 0.11 & 0.38 & 0.18 & 0.03 & 16.7 \\
\hline Oct-05 & 17 Oct 05 & 21.50 & 0.10 & 1.02 & 1.54 & 0.69 & 44.8 \\
\hline Nov-05 & 29 Nov 05 & 16.05 & 0.49 & 4.03 & 0.97 & 0.38 & 39.2 \\
\hline Jan-06 & 18 Jan 06 & 13.00 & 0.06 & 3.36 & 0.47 & 0.09 & 19.1 \\
\hline Mar-06 & 15 Mar 06 & 12.50 & - & - & 1.66 & 0.92 & 55.6 \\
\hline Apr-06 & 4 Apr 06 & 14.20 & 0.15 & 2.35 & 1.13 & 0.59 & 52.2 \\
\hline May-06 & 16 May 06 & 18.10 & 0.08 & 0.05 & 0.95 & 0.38 & 40.0 \\
\hline Jun-06 & 14 Jun 06 & 21.10 & 0.33 & 0.40 & 0.49 & 0.06 & 12.2 \\
\hline Jul-06 & 31 Jul 06 & 24.40 & 0.29 & 0.09 & 0.39 & 0.08 & 20.5 \\
\hline Aug-06 & 29 Aug 06 & 24.40 & 0.11 & 0.08 & 0.31 & 0.03 & 9.7 \\
\hline Sep-06 & 28 Sep 06 & 22.20 & 0.04 & 0.07 & 0.73 & 0.05 & 6.8 \\
\hline
\end{tabular}

Table 1. Environmental and chemical conditions for each experiment. -: no data 
Table 2. Phytoplankton community composition (cells $\mathrm{ml}^{-1}$ ). Values in parentheses are SDs. Note that Nitzschia and Pseudonitzschia spp. are sometimes presented as a group, given we were not able to distinguish between them under light microscopy. nd $=$ not determined

\begin{tabular}{|lcccl|}
\hline Expt & Prochlorococcus & Synechococcus & Diatoms & Dominant diatom genera \\
\hline Sep-05 & $4.5 \times 10^{3}\left(2.5 \times 10^{2}\right)$ & $3.3 \times 10^{4}\left(2.3 \times 10^{3}\right)$ & $6.3(0.69)$ & Guinardia, Chaetoceros \\
Oct-05 & $4.5 \times 10^{4}\left(2.0 \times 10^{3}\right)$ & $5.7 \times 10^{3}\left(1.3 \times 10^{3}\right)$ & $145.9(10.7)$ & Chaetoceros \\
Nov-05 & $4.5 \times 10^{3}\left(6.5 \times 10^{2}\right)$ & $6.4 \times 10^{3}\left(3.5 \times 10^{2}\right)$ & $38.0(1.4)$ & Chaetoceros \\
Jan-06 & $4.3 \times 10^{3}\left(9.2 \times 10^{2}\right)$ & $4.3 \times 10^{3}\left(3.4 \times 10^{2}\right)$ & $24.9(7.0)$ & Chaetoceros \\
Mar-06 & nd & nd & $154.2(32.2)$ & Chaetoceros, Rhizosolenia, Eucampia, Guinardia \\
Apr-06 & nd & nd & $132.1(16.5)$ & Chaetoceros, Rhizosolenia, Guinardia \\
May-06 & 0.0 & $7.1 \times 10^{4}\left(8.6 \times 10^{2}\right)$ & $1180.5(105.3)$ & Pseudo-nitzschia, Dactyliosolen \\
Jun-06 & 0.0 & $4.9 \times 10^{4}\left(1.1 \times 10^{3}\right)$ & $24.0(3.1)$ & Guinardia, Dactyliosolen \\
Jul-06 & 0.0 & $1.9 \times 10^{5}\left(1.2 \times 10^{4}\right)$ & $131.0(21.8)$ & Nitzschia-Pseudo-nitzschia, Leptocylindrus \\
Aug-06 & 0.0 & $1.2 \times 10^{5}\left(4.7 \times 10^{3}\right)$ & $16.9(3.2)$ & Nitzschia-Pseudo-nitzschia, Dactyliosolen \\
Sep-06 & $3.0 \times 10^{4}\left(3.4 \times 10^{3}\right)$ & $1.0 \times 10^{5}\left(1.6 \times 10^{2}\right)$ & $31.4(5.8)$ & Nitzschia-Pseudo-nitzschia, Leptocylindrus \\
& & & & \\
\hline
\end{tabular}

of phytoplankton species composition during the study were a bloom of colonial Phaeocystis sp. in March, and a bloom of the chain-forming diatoms Pseudo-nitzschia sp. and Dactyliosolen fragilissimus in May. Regarding the smallest components of the community, as previously shown (Sommaruga et al. 2005), Prochlorococcus sp. was absent from the plankton during end of spring and beginning of summer, when the abundances of Synechococcus sp. were the highest (Table 2 ). Overall, these 2 groups of prokaryotes are not important components of the community in terms of biomass (Latasa et al. 2005).

The initial biomass of grazers was estimated for the standard (unfiltered) and the $<10 \mu \mathrm{m}$ dilution assays. The biomass of grazers in the unfiltered water spanned

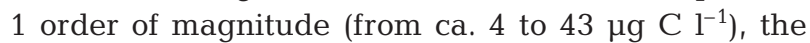
community being dominated by ciliates in April and September 2006, and by flagellated organisms over the rest of the year (Fig. 2A), with no evidence for any clear seasonal pattern.

Filtering through a $10 \mu \mathrm{m}$ mesh drastically reduced the biomass of micrograzers (ciliates + dinoflagellates, average reduction $60 \%$, range 14 to $85 \%$ ) with respect to unfiltered samples, and seldom affected heterotrophic nanoflagellates (average reduction 15\%, Fig. 2B). Interestingly, from May to August the dinoflagellate community in the unfiltered water mainly consisted of $<10 \mu \mathrm{m}$ cells, as evidenced by the smaller reduction in dinoflagellate biomass after size fractionation (0 to $38 \%$, Fig. 2B). The grazers that squeezed through the $10 \mu \mathrm{m}$ mesh (mostly nanoflagellates and small dinoflagellates) are hereafter referred to as nanograzers, as opposed to micrograzers, or microzooplankton, which only include the large ciliates and dinoflagellates not present in the fractionated dilution incubations. For consistency, when we refer to the grazing impact of the whole community of grazers (i.e. standard dilutions with unfiltered water) we use the term microbial grazers.

\section{Standard dilution grazing experiments}

The dilution experiments with unfiltered water provided estimates of growth and grazing rates for total, $>10 \mu \mathrm{m}$, and $<10 \mu \mathrm{m}$ chl a (Table 3). Phytoplankton mortality rates ranged from 0.21 to $0.99 \mathrm{~d}^{-1}$ for total

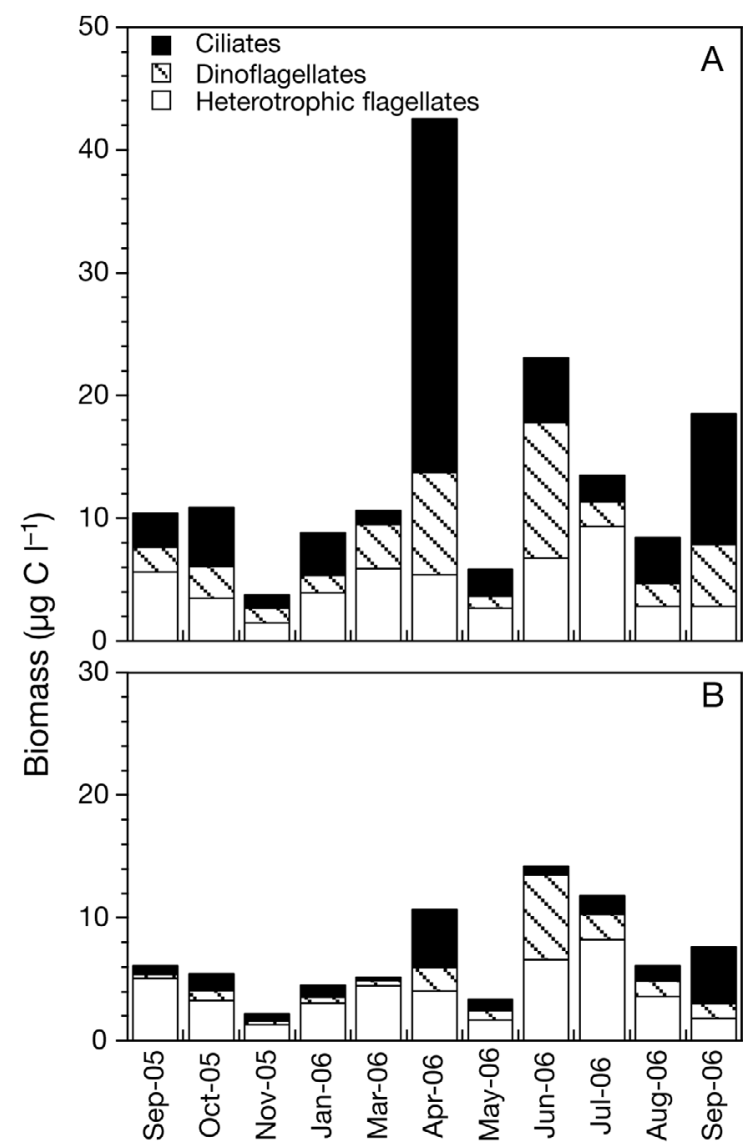

Fig. 2. Initial biomass of the different groups of microbial grazers (see Table 1 for dates and further details). Concentrations in $(\mathrm{A})$ the unfiltered water, $(\mathrm{B})$ the $<10 \mu \mathrm{m}$ samples 
chl a (mean $\left.0.42 \mathrm{~d}^{-1}\right)$, and from non-detectable to 0.89 and $1.7 \mathrm{~d}^{-1}$ for $>10 \mu \mathrm{m}$ (mean $0.23 \mathrm{~d}^{-1}$ ) and $<10 \mu \mathrm{m}$ chl a (mean $0.71 \mathrm{~d}^{-1}$ ), respectively. Only 2 experiments resulted in no significant grazing on $<10 \mu \mathrm{m}$ chl $a$ (January and March, Table 3), whereas we detected significant grazing on $>10 \mu \mathrm{m}$ chl $a$ in 5 experiments (Table 3). On one occasion (May) we obtained a positive slope.

Phytoplankton growth rates ranged from 0.3 to $1.1 \mathrm{~d}^{-1}$ for total chl $a$, from 0.12 to 1.6 for $>10 \mu \mathrm{m}$ chl $a_{\text {, }}$ and from 0.27 to $1.7 \mathrm{~d}^{-1}$ for $<10 \mu \mathrm{m}$ chl a (Table 3), without any evident seasonal pattern. The rates (both for total and the 2 size fractions) did not correlate with temperature, chl a concentrations, or nutrients (no significant correlations at $\mathrm{p}<0.05)$. However, the net growth rates on the nutrient-unamended bottles showed distinct seasonal patterns. During late summer months (from the end of July to September 2006), net growth rates were close to $0 \mathrm{~d}^{-1}$, showing a dynamic equilibrium between phytoplankton growth and mortality. Over the rest of the year these rates were positive, indicative of an increasing phytoplankton community. This is also consistent with the percentage of PP consumed daily, based on the ratio of

Table 3. Phytoplankton growth $(\mu)$ and mortality $(m)$ rates from unfiltered (standard) dilution experiments for total chl $a_{1}>10 \mu m$ and $<10 \mu \mathrm{m} \mathrm{chl} a$. Values in parentheses are $95 \%$ CIs of the slope. $\mu_{0}=$ net growth rate in the bottles without nutrients addition; $\mu=$ instantaneous growth rate $\left(\mu=\mu_{0}+m\right)$ without nutrient addition; PP = primary production derived from $\mu$ (see 'Materials and methods'); \% PP = percentage of PP at each size-fraction daily removed by grazing; \% SS = percentage of the phytoplankton standing stock daily removed by grazing; $\mathrm{ns}=$ not significant; ${ }^{*} \mathrm{p}<0.05_{i}{ }^{* *} \mathrm{p}<0.01$

\begin{tabular}{|c|c|c|c|c|c|c|c|}
\hline Expt & $\begin{array}{c}m \\
\left(\mathrm{~d}^{-1}\right)\end{array}$ & $\mathrm{r}^{2}$ & $\begin{array}{c}\mu_{0} \\
\left(d^{-1}\right)\end{array}$ & $\begin{array}{c}\mu \\
\left(d^{-1}\right)\end{array}$ & $\begin{array}{c}\text { PP } \\
\left(\mu \mathrm{g} \mathrm{chl} a \mathrm{l}^{-1} \mathrm{~d}^{-1}\right)\end{array}$ & $\% \mathrm{PP}$ & $\% \mathrm{SS}$ \\
\hline \multicolumn{8}{|l|}{ Total chl } \\
\hline Sep-05 & $0.36(-0.66,-0.054)$ & $0.58^{*}$ & 0.64 & 1.00 & 0.25 & 36.0 & 50.4 \\
\hline Oct-05 & $0.38(-0.71,-0.052)$ & $0.57^{*}$ & 0.48 & 0.86 & 1.70 & 44.2 & 48.8 \\
\hline Nov-05 & $0.27(-0.44,-0.94)$ & $0.70^{* *}$ & 0.35 & 0.62 & 0.72 & 43.5 & 32.3 \\
\hline Jan-06 & $0.08\left(-0.16,-7.6 \times 10^{-5}\right)$ & $0.57^{*}$ & 0.30 & 0.30 & 0.16 & 26.7 & 8.9 \\
\hline Mar-06 & $0.23(-0.39,-0.068)$ & $0.80^{*, a}$ & 0.36 & 0.59 & 1.18 & 39.0 & 27.7 \\
\hline Apr-06 & $0.38(-0.69,-0.077)$ & $0.61^{*}$ & 0.57 & 0.95 & 1.44 & 40.1 & 51.1 \\
\hline May-06 & $0.21(-0.33,-0.099)$ & $0.77^{* *}$ & 0.65 & 0.86 & 1.15 & 24.4 & 29.6 \\
\hline Jun-06 & $0.82(-1.20,-0.45)$ & $0.83^{* *}$ & 0.26 & 1.08 & 0.60 & 76.3 & 93.4 \\
\hline Jul-06 & $0.99(-1.54,-0.43)$ & $0.76^{* *}$ & -0.04 & 0.96 & 0.37 & 103.7 & 97.3 \\
\hline Aug-06 & $0.50(-1.02,0.019)$ & $0.48^{*}$ & 0.01 & 0.51 & 0.16 & 97.3 & 50.4 \\
\hline Sep-06 & $0.36(-0.64,-0.068)$ & $0.60^{* *}$ & 0.07 & 0.43 & 0.33 & 82.8 & 37.0 \\
\hline \multicolumn{8}{|c|}{$>10 \mu \mathrm{m} \mathrm{chl}$} \\
\hline Sep-05 & $0.36(-0.62,-0.092)$ & $0.65^{*}$ & 1.20 & 1.56 & 0.09 & 23.1 & 69.6 \\
\hline Oct-05 & $\mathrm{ns}$ & ns & 0.63 & 0.63 & 0.60 & 0.0 & 0.0 \\
\hline Nov-05 & ns & ns & 0.37 & 0.37 & 0.17 & 0.0 & 0.0 \\
\hline Jan-06 & ns & ns & 0.52 & 0.52 & 0.06 & 0.0 & 0.0 \\
\hline Mar-06 & $0.20(-0.32,-0.078)$ & $0.78^{*, a}$ & 0.27 & 0.45 & 0.48 & 42.5 & 23.0 \\
\hline Apr-06 & ns & ns & 0.48 & 0.48 & 0.36 & 0.0 & 0.0 \\
\hline May-06 & ns & $0.57^{*, b}$ & 0.12 & 0.12 & 0.05 & 0.0 & 0.0 \\
\hline Jun-06 & $0.67(-0.92,-0.42)$ & $0.88^{* *}$ & 0.43 & 1.10 & 0.08 & 60.9 & 83.7 \\
\hline Jul-06 & $0.89(-1.30,-0.48)$ & $0.90^{*, a}$ & 0.71 & 1.60 & 0.19 & 55.6 & 129.6 \\
\hline Aug-06 & $0.43(-0.63,-0.24)$ & $0.90^{* *, a}$ & 0.18 & 0.61 & 0.02 & 70.5 & 47.1 \\
\hline Sep-06 & $\mathrm{ns}$ & ns & 0.31 & 0.31 & 0.02 & 0.0 & 0.0 \\
\hline \multicolumn{8}{|c|}{$<10 \mu \mathrm{m}$ chl } \\
\hline Sep-05 & $0.35(-0.69,-0.002)$ & $0.50^{*}$ & 0.47 & 0.81 & 0.16 & 42.7 & 44.2 \\
\hline Oct-05 & $0.70(-1.34,-0.05)$ & $0.53^{*}$ & 0.31 & 1.00 & 0.99 & 69.5 & 81.3 \\
\hline Nov-05 & $0.44(-0.84,-0.04)$ & $0.61^{*}$ & 0.38 & 0.82 & 0.59 & 53.7 & 53.5 \\
\hline Jan-06 & $\mathrm{ns}$ & $\mathrm{ns}$ & 0.27 & 0.27 & 0.12 & 0.00 & 0.0 \\
\hline Mar-06 & ns & ns & 0.49 & 0.49 & 0.47 & 0.00 & 0.0 \\
\hline Apr-06 & $0.91(-1.74,-0.09)$ & $0.55^{*}$ & 0.29 & 1.21 & 0.76 & 75.7 & 106.3 \\
\hline May-06 & $0.47(-0.65,-0.28)$ & $0.87^{* *}$ & 0.86 & 1.33 & 1.20 & 35.0 & 73.9 \\
\hline Jun-06 & $0.81(-1.21,-0.40)$ & $0.80^{* *}$ & 0.21 & 1.02 & 0.49 & 79.2 & 89.9 \\
\hline Jul-06 & $1.28(-2.34,-0.22)$ & $0.60^{*}$ & -0.45 & 0.83 & 0.21 & 154.5 & 103.0 \\
\hline Aug-06 & $1.75(-4.13,0.64)$ & $0.83^{\mathrm{c}}$ & 0.00 & 1.70 & 0.47 & 100.3 & 169.6 \\
\hline Sep-06 & $0.43(-0.78,-0.08)$ & $0.60^{*}$ & 0.06 & 0.49 & 0.34 & 88.0 & 44.0 \\
\hline
\end{tabular}


grazing to growth (Fig. 3). This percentage ranged from 0 to $104 \%$ for total chl $a_{\text {, }}$ and from 0 to $70 \%$ and $148 \%$ for $>10 \mu \mathrm{m}$ and $<10 \mu \mathrm{m} \mathrm{chl} a$, respectively. On average, microbial grazer activity daily removed $56 \%$ of total $\mathrm{PP}$, and 23 and $58 \%$ of the $>10 \mu \mathrm{m}$ and $<10 \mu \mathrm{m}$ PP, respectively (Table 3 ). The percentages of the phytoplankton standing stock consumed daily ranged from 9 to $97 \%$ for total $\mathrm{chl} a_{\text {, }}$ and from 0 to $130 \%$ and $170 \%$ for $>10 \mu \mathrm{m}$ and $<10 \mu \mathrm{m} \mathrm{chl} a_{\text {, }}$ respectively (Table 3 ).

Our dilution experiments did not allow for direct characterization of the distinct grazing impact of the different microbial grazers, although we can try to relate the composition of the microbial herbivore community with the observed grazing rates. We found a significant relationship only between phytoplankton mortality rates (grazing rates) and heterotrophic flagellate biomass and temperature. Neither the ciliate biomass nor the dinoflagellate biomass were related directly to the variability of phytoplankton mortality rates (Fig. 4).

\section{Size-fractionated dilution grazing experiments}

In these experiments we truncated the planktonic community and eliminated both large grazers and large prey, in order to obtain the potential control on small primary producers by nanograzers when these have been released from predation pressure. The initial chl a (Table 4) followed the pattern described above for the natural community, and therefore it will not be further discussed. The mortality rates of phytoplankton for this treatment ranged from not detectable ( 2 experiments) to $0.76 \mathrm{~d}^{-1}$ (average $0.35 \mathrm{~d}^{-1}$, Table 4). Phytoplankton growth rates spanned 1 order of magnitude, from 0.07 to $1.15 \mathrm{~d}^{-1}$, with the average being slightly lower than that of the unfiltered treatments $\left(0.6 \mathrm{~d}^{-1}\right.$, Table 4$)$. The impact of nanozooplankton grazing activity on $<10 \mu \mathrm{m}$ phytoplankton was quite variable, with daily consumption ranging from 0 to $140 \%$ of the PP, and from 0 to $70 \%$ of the standing stock.

For comparative purposes Fig. 3B shows the $m: \mu$ quotient for these experiments (size-fractionated dilutions) and the ones obtained for $<10 \mu \mathrm{m}$ chl $a$ in standard (unfiltered) dilutions. Higher quotients for the size-fractionated dilutions would mean that the nanograzer community was actively feeding on $<10 \mu \mathrm{m}$ phytoplankton, but this grazing was not expressed under natural conditions because the grazer abundance was heavily controlled by larger predators (microzooplankton $>10 \mu \mathrm{m}$ ). These situations mostly occurred during the spring. The opposite response would mean that microzooplankton $>10 \mu \mathrm{m}$ are important grazers of the community, and removing them
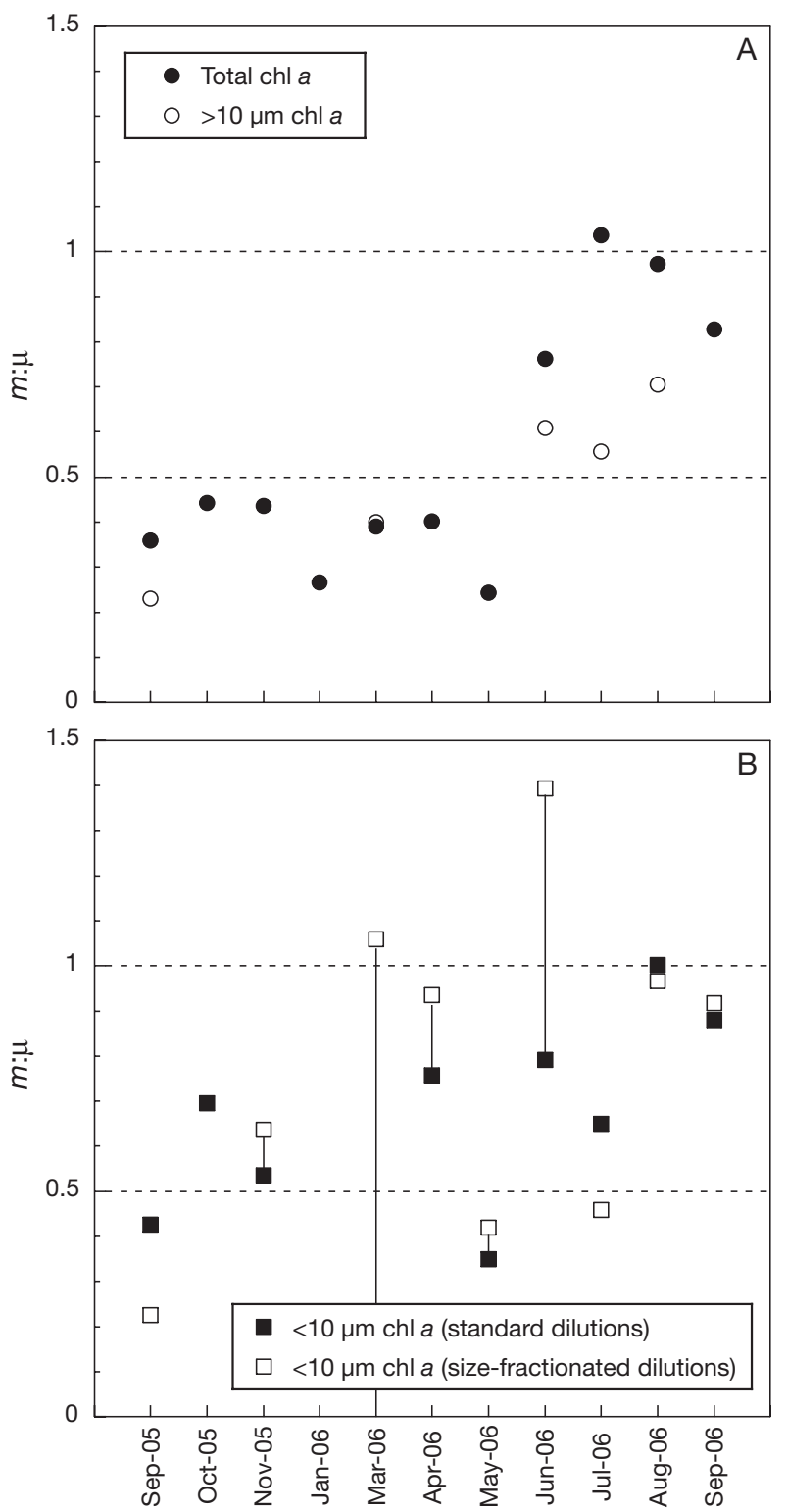

Fig. 3. Proportion of primary production consumed by microbial grazers throughout a seasonal cycle. Data are derived as the ratio of grazing mortality to growth rate $(m: \mu)$ from dilution experiments. For reference, the dashed lines labeled 1.0 and 0.5 refer, respectively, to grazing mortalities equal to 100 and $50 \%$ of concurrent estimates of phytoplankton growth. (A) Standard (unfiltered) dilution experiments for total and $>10 \mu \mathrm{m}$ chl $a$. (B) $<10 \mu \mathrm{m} \mathrm{chl} \mathrm{a} \mathrm{for} \mathrm{standard} \mathrm{(unfiltered)} \mathrm{and}$ size-fractionated through $10 \mu \mathrm{m}$ dilution experiments. The enhancing effect of the removal of $>10 \mu \mathrm{m}$ grazers on the grazing impact in the size-fractionated experiments is stressed with vertical solid lines

from the experiments would result in higher phytoplankton net growth rates. Finally, when no differences were detected between treatments (end of summer 2006), we saw a community of grazers dominated by nano-sized organisms, weakly top-down controlled. 

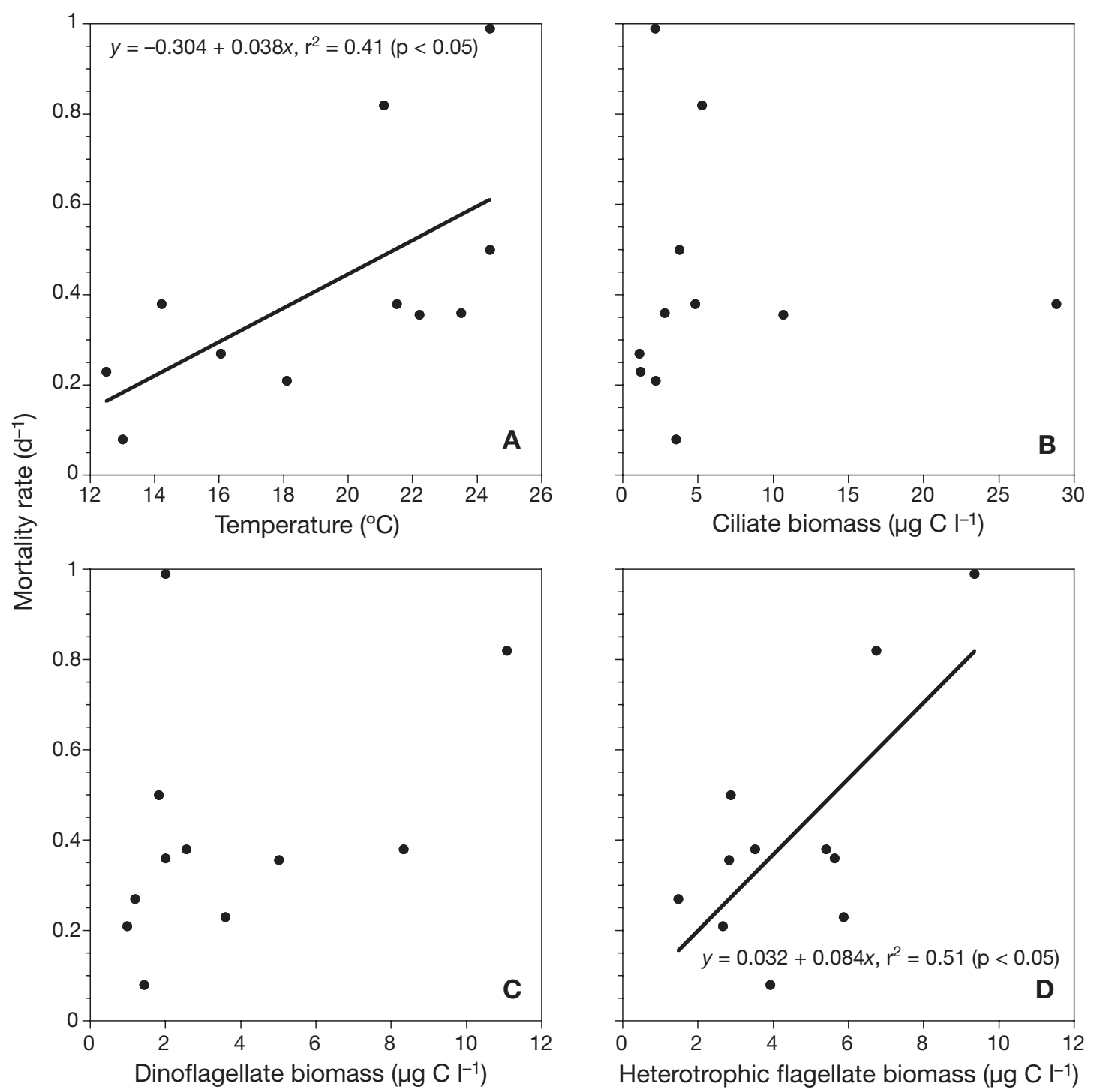

Fig. 4. Relationship between phytoplankton mortality rates in standard (unfiltered) dilution experiments and (A) temperature, (B) ciliate biomass, (C) dinoflagellate biomass, and (D) heterotrophic flagellate biomass. A significant relationship was found only with temperature and heterotrophic flagellate biomass

\section{DISCUSSION}

\section{Redefining the nanoplankton concept}

A first outcome of the study, backed up by previous studies (Reckermann \& Veldhuis 1997, Lessard \& Murrell 1998, authors' unpubl. data), is that screening through $10 \mu \mathrm{m}$ meshes seems to better shape the intuitive functional groups of the small planktonic community than the standard $20 \mu \mathrm{m}$ mesh (Seiburth \& Smetaceck 1978). Either because most ciliates and dinoflagellates are too large to fit through the mesh, or because they get damaged during the filtration process, $10 \mu \mathrm{m}$ filtration seems to better discriminate flagellates, small dinoflagellates, and small ciliates (nanograzers) from large ciliates and large dinoflagellates (micrograzers). Therefore, we tentatively recommend the use of $10 \mu \mathrm{m}$ (and even smaller mesh sizes, since some ciliates and dinoflagellates passed through the $10 \mu \mathrm{m}$ mesh) as a standard for categorization of flagellate grazers. Nevertheless, the particular nature of the size spectrum of organisms of diverse ecosystems calls for further tests until a more robust body of information is assembled.

\section{Phytoplankton mortality and growth rates}

Our dilution experiments using unscreened water rendered unique data on phytoplankton growth and 
Table 4. Phytoplankton growth $(\mu)$ and mortality $(m)$ rates from the $<10 \mu \mathrm{m}$ size-fractionated dilution experiments. Both phytoplankton and grazers are $<10 \mu \mathrm{m}$. Chl $a=$ initial concentration of chl $a$ for these experiments; $m=$ grazing mortality rates (values in parentheses are $95 \%$ CIs of the slope); $\mu_{0}=$ net growth rate in the bottles without nutrient amendment; $\mu=$ instantaneous growth rate $\left(\mu=\mu_{0}+m\right)$ without nutrient amendment; PP = primary production derived from $\mu$ (see 'Materials and methods'); \% $\mathrm{PP}=$ percentage of the $<10 \mu \mathrm{m}$ PP daily removed by grazing; $\% \mathrm{SS}=$ percentage of the $<10 \mu \mathrm{m}$ phytoplankton standing stock daily removed by grazing; $\%$ Nano = contribution of $<10 \mu \mathrm{m}$ grazers to total grazer community biomass; ns = not significant; ${ }^{*} \mathrm{p}<0.05 ;{ }^{* *} \mathrm{p}<0.01$

\begin{tabular}{|c|c|c|c|c|c|c|c|c|c|}
\hline Expt & $\begin{array}{c}\mathrm{Chl} \mathrm{a} \\
\left(\mu \mathrm{g} \mathrm{l}^{-1}\right)\end{array}$ & $\underset{\left(d^{-1}\right)}{m}$ & $\mathrm{r}^{2}$ & $\begin{array}{c}\mu_{0} \\
\left(d^{-1}\right)\end{array}$ & $\begin{array}{c}\mu \\
\left(d^{-1}\right)\end{array}$ & $\begin{array}{l}\text { PP } \\
\text { hl } a \mathrm{l}^{-1}\end{array}$ & 1) $\%$ PP & $\% \mathrm{SS}$ & $\%$ Nano \\
\hline Sep-05 & 0.16 & $0.26(-0.52,-0.01)$ & $0.52^{*}$ & 0.89 & 1.15 & 0.30 & 22.6 & 41.9 & 58.8 \\
\hline Oct-05 & 0.86 & ns & ns & 0.48 & 0.48 & 0.53 & 0.0 & 0.0 & 50.5 \\
\hline Nov-05 & 0.58 & $0.21(-0.40,-0.01)$ & $0.60^{*}$ & 0.12 & 0.33 & 0.20 & 63.6 & 22.3 & 58.7 \\
\hline Jan-06 & 0.41 & ns & ns & 0.07 & 0.07 & 0.00 & 0.0 & 0.0 & 50.9 \\
\hline Mar-06 & 0.63 & $0.50(-0.83,-0.16)$ & $0.69^{* *}$ & -0.03 & 0.47 & 0.29 & 106.4 & 49.3 & 48.9 \\
\hline Apr-06 & 0.46 & $0.33(-0.61,-0.04)$ & $0.57^{*}$ & 0.02 & 0.35 & 0.16 & 93.5 & 33.4 & 25.1 \\
\hline May-06 & 0.55 & $0.39(-0.59,-0.18)$ & $0.78^{* *}$ & 0.55 & 0.94 & 0.68 & 41.7 & 51.2 & 58.0 \\
\hline Jun-06 & 0.51 & $0.76(-1.00,-0.52)$ & $0.91^{* *}$ & -0.22 & 0.55 & 0.25 & 139.4 & 68.4 & 61.5 \\
\hline Jul-06 & 0.30 & $0.42(-0.72,-0.13)$ & $0.67^{*}$ & 0.50 & 0.92 & 0.19 & 45.9 & 54.4 & 87.6 \\
\hline Aug-06 & 0.30 & $0.64(-0.85,-0.43)$ & $0.90^{* *}$ & 0.02 & 0.66 & 0.20 & 96.7 & 64.7 & 72.3 \\
\hline Sep-06 & 0.62 & $0.43(-0.69,-0.18)$ & $0.74^{* *}$ & 0.04 & 0.47 & 0.30 & 91.7 & 61.2 & 41.2 \\
\hline
\end{tabular}

mortality rates in the coastal NW Mediterranean. Previous reports of microzooplankton grazing upon the phytoplankton community in Mediterranean waters were either restricted to particular semi-enclosed environments, such as harbors during harmful algal bloom episodes (Calbet et al. 2003, Garcés et al. 2005), and lagoons (Collos et al. 2005), or to open waters for a limited period of time (June; Latasa et al. 2005). The phytoplankton mortality and growth rates obtained in the present study are in the wide range of values reported for coastal ecosystems (Landry \& Hassett 1982, Burkill et al. 1987, Neuer \& Cowles 1994, Archer et al. 2000, Fileman et al. 2002), and the average percentage of PP daily consumed by microzooplankton (56\%) is close to that expected for coastal waters $(60 \%$, Calbet \& Landry 2004).

Microbial grazers appeared to heavily control primary producers during summer 2006. From late July to September the net growth rates of the phytoplankton community were close to zero in the unamended bottles, as a result of a strong coupling between phytoplankton growth and mortality rates. Nutrients were low, especially ammonium, which could have favored reduced growth rates. However, the natural rates obtained from the dilution experiments (Table 3) revealed an actively growing phytoplankton community that obtained their nourishment likely from recycled nutrients. For the rest of the year, on the other hand, grazing impact seemed less coupled with phytoplankton growth, which resulted in an increase of phytoplankton communities with uncertain fate. Since the mesozooplankton of the area seem unable to cope with the remaining production (Broglio et al. 2004, Atienza et al. 2006), other mechanisms such as advec- tion or sedimentation losses (Estrada et al. 1999) have to be invoked.

Regarding the larger phytoplankton size fraction, microzooplankton grazing on $>10 \mu \mathrm{m}$ phytoplankton was only detected in 5 experiments, which contrasts with increasing evidence for microzooplankton controlling populations of large phytoplankters (Sherr \& Sherr 1992, Strom \& Strom 1996, Stelfox-Widdicombe et al. 2004, Jeong et al. 2005, Leising et al. 2005). Surprisingly, 4 of these experiments corresponded to the summer season, when the contribution of $>10 \mu \mathrm{m}$ cells to the total phytoplankton biomass was the lowest, and the other one (March) coincided with a bloom of the colonial algae Phaeocystis sp. This species can be grazed by microzooplankton when in solitary form, but not when forming colonies (Stelfox-Widdicombe et al. 2004, Nejstgaard et al. 2006). We discard the idea that there was grazing on large colonies, and rather conjecture that the sizable mortality of $>10 \mu \mathrm{m}$ phytoplankton was the result of grazing on diatom chains and other large phytoplankton accompanying the bloom. Indeed, in the coastal NW Mediterranean very large phytoplankton are usually dominant only during the seasonal blooms (spring, early fall, and late winter; Duarte et al. 1999, Ribera d'Alcalà et al. 2004). It appears that our discrete sampling did not coincide with any such blooms. In May, nevertheless, we observed a small diatom bloom of Pseudo-nitzschia sp. and Dactyliosolen sp. Puzzlingly, we obtained a positive slope for grazing mortality (Table 3 ). We do not have a solid explanation for this positive slope, which might result either from strong trophic cascade effects during the incubations (see 'Introduction'), or from complex cycling of nutrients between internal and 
external pools (Landry 1993) as nutrients would be taken by smaller algae more efficiently and would become limiting for larger phytoplankton (in situ nutrients were very low).

\section{Seasonal patterns of trophic food-web interactions}

From our regression analyses we concluded that temperature and flagellated phagotrophs are important drivers of the variability in phytoplankton mortality rates, whereas ciliates seem to play a surprisingly minor role in the general dynamic of the system as grazers of primary producers. We cannot ignore, however, that ciliates and dinoflagellates may be relevant episodically, as possibly occurred during April, when a bloom of Laboea sp. occurred. The presence of chlorophyll in this mixotrophic species may have hampered a correct interpretation of the dilution experiment and induced an underestimation of the actual microzooplankton grazing rates. Temperature also appeared to be relevant, influencing phytoplankton mortality through grazing. Besides the obvious effects of temperature as an accelerator of metabolic and physiological activities, such as ingestion rates (Rassoulzadegan 1982, Ikeda 1985), we believe it might have also influenced the food-web scenario indirectly. Warmer, more stratified waters usually are nutrient-deficient, less productive, and dominated by smaller cells, which are more susceptible to predation.

Heterotrophic flagellates indeed were the obvious candidates as the main grazers of a community mostly dominated by $<10 \mu \mathrm{m}$ algae. By carefully examining the $<10 \mu \mathrm{m}$ size-fractionated dilution experiments we can observe the potential impact of nanograzers ( $<10 \mu \mathrm{m}$, mostly flagellates, and occasionally small dinoflagellates and ciliates) on primary producers. The phytoplankton mortality rates obtained in these experiments were higher than those upon $<10 \mu \mathrm{m}$ chl $a$ obtained from the standard (unfiltered) experiments mostly during the spring (Fig. 3). The only plausible explanation is that large microzooplankton were controlling the abundance of the actual grazers (nanosized protists) of the small-sized dominant primary producers, setting for these springtime experiments a trophic cascade where phytoplankton is consumed by nanograzers, which in turn are the prey of microzooplankton (ciliates and large dinoflagellates). Further experiments truncating the food web in more detail (different size classes) would likely complicate this picture, as has been observed in other oligotrophic areas (Reckermann \& Veldhuis 1997, Calbet et al. 2001).

Clear exceptions to this general picture were seen in in May. Quite likely, during these experiments, which coincided with a bloom of small diatoms, many thin diatom chains passed through the $10 \mu \mathrm{m}$ mesh in the size-fractionated dilution experiments, introducing large prey not edible for $<10 \mu \mathrm{m}$ grazers into the experimental bottles.

In summertime the situation was different. Nanograzers (heterotrophic flagellates and small ciliates and dinoflagellates) seemed to escape the control (topdown control) of microzooplankton and became the dominant grazers of the community by late summer. Nanograzers were exerting a relatively high and constant grazing pressure on phytoplankton, their abundance, therefore, being largely bottom-up controlled. It is also during this period when the contribution of $<10 \mu \mathrm{m} \mathrm{chl}$ a to total chl a was higher ( $\geq 80 \%)$.

In summary, in light of the evidence presented here, microzooplankton should not be considered a homogeneous group; if so, we would miss important insights in the functioning of marine food webs. For instance, the relatively constant grazing impact of microzooplankton in contrasting ecosystems compiled by Calbet \& Landry (2004) could well be the result of very different food-web scenarios, with distinct implications for the nutrient and organic matter dynamics (longer and more complex food webs supporting a proportionally higher rate of nutrient recycling). In this sense, multiple food chain models would approach reality more closely than one-phytoplankton-one-zooplankton models (NPZ). This is particularly so in those domains where nutrients are virtually all used up during the growing season and multiple levels of grazers are required to account for the dynamics of the system, and where top-down and bottom-up controls of the community shift over the year (Armstrong 1994).

Acknowledgements. This work was funded by grant CTM2004-02575/MAR from the Ministry of Education and Science of Spain, PhD fellowships to R.A. and V.S. from the same ministry, and an I3P contract to L.Y. from the CSIC. We thank 3 reviewers and R. W. Sanders for their very helpful and constructive comments.

\section{LITERATURE CITED}

Agis M, Granda A, Dolan JR (2007) A cautionary note: examples of possible microbial community dynamics in dilution grazing experiments. J Exp Mar Biol Ecol 341:176-183

Archer SD, Verity PG, Stefels J (2000) Impact of microzooplankton on the progression and fate of the spring bloom in fjords of northern Norway. Aquat Microb Ecol 22:27-41

Armstrong RA (1994) Grazing limitation and nutrient limitation in marine ecosystems: steady state solutions of an ecosystem model with multiple food chains. Limnol Oceanogr 39:597-608

Atienza D, Calbet A, Saiz E, Alcaraz M, Trepat I (2006) Trophic impact, metabolism, and biogeochemical role of the marine cladoceran Penilia avirostris and the co-dominant copepod Oithona nana in NW Mediterranean coastal waters. Mar Biol 150:221-235 
Børsheim KY, Bratbak G (1987) Cell volume to cell carbon conversion factors for a bacterivorous Monas sp. enriched from seawater. Mar Ecol Prog Ser 36:171-175

Broglio E, Saiz E, Calbet A, Trepat I, Alcaraz M (2004) Trophic impact and prey selection by crustacean zooplankton on the microbial communities of an oligotrophic coastal area (NW Mediterranean Sea). Aquat Microb Ecol 35:65-78

Burkill PH, Mantoura RFC, Llewellyn CA, Owens NJP (1987) Microzooplankton grazing and selectivity of phytoplankton in coastal waters. Mar Biol 93:581-590

Calbet A (2001) Mesozooplankton grazing effect on primary production: a global comparative analysis in marine ecosystems. Limnol Oceanogr 46:1824-1830

Calbet A, Landry MR (1999) Mesozooplankton influences on the microbial food web: direct and indirect trophic interactions in the oligotrophic open ocean. Limnol Oceanogr 44:1370-1380

Calbet A, Landry MR (2004) Phytoplankton growth, microzooplankton grazing, and carbon cycling in marine systems. Limnol Oceanogr 49:51-57

Calbet A, Landry MR, Nunnery S (2001) Bacteria-flagellate interactions in the microbial food web of the oligotrophic subtropical North Pacific. Aquat Microb Ecol 23:283-292

Calbet A, Vaqué D, Felipe J, Vila M, Sala MM, Alcaraz M, Estrada M (2003) Relative grazing impact of microzooplankton and mesozooplankton on a bloom of the toxic dinoflagellate Alexandrium minutum. Mar Ecol Prog Ser 259:303-309

C Collos Y, Descolas-Gros C, Mornet F (2005) Grazing affects carbon fixation pathways by phytoplankton in coastal marine ecosystems. Chem Ecol 21:503-509

Dolan JR, McKeon K (2005) The reliability of grazing rate estimates from dilution experiments: Have we over-estimated rates of organic carbon consumption by microzooplankton? Ocean Sci 1:1-7

Dolan JR, Gallegos CL, Moigis A (2000) Dilution effects on microzooplankton in dilution grazing experiments. Mar Ecol Prog Ser 200:127-139

Duarte CM, Agustí S, Kennedy H, Vaqué D (1999) The Mediterranean climate as a template for Mediterranean marine ecosystems: the example of the NE Spanish littoral. Prog Oceanogr 44:245-270

Estrada M, Varela RA, Salat J, Cruzado A, Arias E (1999) Spatio-temporal variability of the winter phytoplankton distribution across the Catalan and North Balearic fronts (NW Mediterranean). J Plankton Res 21:1-20

Fileman ES, Cummings DG, Llewllyn CA (2002) Microplankton community structure and the impact of microzooplankton grazing during an Emiliania huxleyi bloom, off the Devon coast. J Mar Biol Assoc UK 82:359-368

Gallegos CL (1989) Microzooplanton grazing on phytoplankton in the Rhode River, Maryland: nonlinear feeding kinetics. Mar Ecol Prog Ser 57:23-33

> Garcés E, Vila M, Masó M, Sampedro N, Giacobbe MG, Penna A (2005) Taxon-specific analysis of growth and mortality rates of harmful dinoflagellates during bloom conditions. Mar Ecol Prog Ser 301:67-79

Gifford DJ (1985) Laboratory culture of marine planktonic oligotrichs (Ciliophora, Oligotrichida). Mar Ecol Prog Ser 23:257-267

Grasshoff K, Kremling K, Ehrhardt M (eds) (1999) Methods of seawater analysis. Wiley-VCH, Weinheim

Ikeda T (1985) Metabolic rates of epipelagic marine zooplankton as a function of body mass and temperature. Mar Biol 85:1-11

Jeong HJ, Kim JS, Kim JH, Kim ST and others (2005) Feeding and grazing impact of the newly described heterotrophic dinoflagellate Stoeckeria algicida on the harmful alga Heterosigma akashiwo. Mar Ecol Prog Ser 295:69-78

Landry MR (1993) Estimating rates of growth and grazing mortality of phytoplankton by the dilution method. In: Kemp PF, Sherr BF, Sherr EB, Cole JL (eds) Handbook of methods in aquatic microbial ecology. Lewis Publishers, Boca Raton, FL, p 715-722

Landry MR, Hassett RP (1982) Estimating the grazing impact of marine micro-zooplankton. Mar Biol 67:283-288

Landry MR, Constantinou J, Latasa M, Brown SL, Bidigare RR, Ondrusek ME (2000) Biological response to iron fertilization in the eastern equatorial Pacific (IronEx II). III. Dynamics of phytoplankton growth and microzooplankton grazing. Mar Ecol Prog Ser 201:57-72

Latasa M, Morán XAG, Scharek R, Estrada M (2005) Estimating the carbon flux through main phytoplankton groups in the northwestern Mediterranean. Limnol Oceanogr 50:1447-1458

Leising AW, Horner R, Pierson JJ, Postel J, Halsband-Lenk C (2005) The balance between microzooplankton grazing and phytoplankton growth in a highly productive estuarine fjord. Prog Oceanogr 67:366-383

Lessard EJ, Murrell MC (1998) Microzooplankton herbivory and phytoplankton growth in the northwestern Sargasso Sea. Aquat Microb Ecol 16:173-188

Menden-Deuer S, Lessard EJ (2000) Carbon to volume relationships for dinoflagellates, diatoms, and other protist plankton. Limnol Oceanogr 45:569-579

Nejstgaard J, Frischer M, Verity P, Anderson J and others (2006) Plankton development and trophic transfer in seawater enclosures with nutrients and Phaeocystis pouchetii added. Mar Ecol Prog Ser 321:99-121

Neuer S, Cowles TJ (1994) Protist herbivory in the Oregon upwelling system. Mar Ecol Prog Ser 113:147-162

Parsons TR, Maita Y, Lalli CM (1984) A manual of chemical and biological methods for sea water analysis. Pergamon, Oxford

Putt M, Stoecker DK (1989) An experimentally determined carbon: volume ratio for marine 'oligotrichous' ciliates from estuarine and coastal waters. Limnol Oceanogr 34:1097-1103

Rassoulzadegan F (1982) Dependence of grazing rate, gross growth efficiency and food size range on temperature in a pelagic oligotrichous ciliate Lohmanniella spriralis Leeg., fed on naturally occuring particulate matter. Ann Inst Océanogr 58:177-184

Reckermann M, Veldhuis MJW (1997) Trophic interactions between picophytoplankton and micro- and nanozooplankton in the western Arabian Sea during the NE monsoon 1993. Aquat Microb Ecol 12:263-273

Ribera d'Alcalà M, Conversano F, Corato F, Licandro $\mathrm{P}$ and others (2004) Seasonal patterns in plankton communities in a pluriannual time series at a coastal Mediterranean site (Gulf of Naples): an attempt to discern recurrences and trends. Sci Mar 68:65-83

Seiburth JM, Smetacek VS, Lenz J (1978) Pelagic ecosystem structure: heterotrophic compartments of the plankton and their relationship to plankton size fractions. Limnol Oceanogr 23:1256-1263

Sherr E, Sherr B (1988) Role of microbes in pelagic food webs: a revised concept. Limnol Oceanogr 33:1225-1227

Sherr EB, Sherr BF (1992) Trophic role of pelagic protists: phagotrophic flagellates as herbivores. Arch Hydrobiol Beih Ergebn Limnol 37:165-172

Sommaruga R, Hofer JS, Alonso-Sáez L, Gasol JM (2005) Differential sunlight sensitivity of picophytoplankton from surface Mediterranean coastal waters. Appl Environ 
Microbiol 71:2154-2157

Stelfox-Widdicombe CE, Archer SD, Burkill PH, Stefels J (2004) Microzooplankton grazing in Phaeocystis and diatom-dominated waters in the southern North Sea in spring. J Sea Res 51:37-51

Strom SL, Strom MW (1996) Microzooplankton growth, grazing, and community structure in the northern Gulf of Mexico. Mar Ecol Prog Ser 130:229-240

Turner JT (2004) The importance of small planktonic cope-

Editorial responsibility: Robert Sanders,

Philadelphia, Pennsylvania, USA pods and their roles in pelagic marine food webs. Zool Stud 43:255-266

Verity PG, Langdon C (1984) Relationships between lorica volume, carbon, nitrogen, and ATP content of tintinnids in Narragansett Bay. J Plankton Res 6:859-868

Wikner J, Hagström Å (1988) Evidence for a tightly coupled nanoplanktonic predator-prey link regulating the bacterivores in the marine environmnet. Mar Ecol Prog Ser 50:137-145

Submitted: May 15, 2007; Accepted: December 6, 2007 Proofs received from author(s): January 25, 2008 